\title{
The Resource Curse Syndrome and Legitimate Expectations of the Niger Delta People of Nigeria
}

\author{
Dr Endurance Oriakhi \\ School of law, Business \& Social Sciences, Abertay University, Dundee
}

\begin{abstract}
Nigeria is one of the world's petroleum regions, endowed with an abundance of natural resources necessary for the nation's development. There should be an effective utilization of the resources for the greater good of the country. Each Government endowed with petroleum resources should take action to ensure that those resources are transformed for the benefit of its citizens. The article, reviewing the resource curse theory and scholarship, argues that Nigeria's Niger Delta has significant petroleum resources, but these resources have not been harnessed efficiently for the effective growth of the nation. This has had a considerable impact on the regional distribution of economic advantages, creating a case of the paradox of plenty. It demonstrated the resource curse syndrome in Nigeria and the effort to address the situation. The article presents a proposal on how Nigeria should use and manage its petroleum resources through proactive measures aimed at addressing the resource curse.
\end{abstract}

Keywords: Resource curse; Petroleum resources; Dutch diseases; Niger Delta

DOI: $10.7176 / J R D M / 79-04$

Publication date:October $31^{\text {st }} 2021$

\section{INTRODUCTION}

There are a series of political and economic challenges that have bedevilled Nigeria because of its oil-centric economy (Ariweriokuma, 2008). The economic development of the country is hinged on oil and gas. The overreliance on oil wealth has been a strong challenge for the people of the Niger Delta that are at the receiving end. The economic well-being of the people of the Niger Delta has been adversely affected by the exploitation of petroleum resources in the region (Okonta and Oronto, 2001). Natural resources' curse falls within the discourse in the realm of political economy (Ko, 2014). It has a correlation with economic development and the management of resources. A natural resource curse is defined as a situation in which countries with abundant natural resources have failed to achieve the development and public welfare benefits that would have accrued to them (Natural Resource Governance Institute, 2015).

It is reasonable to expect that countries with a greater wealth of natural resources will perform better economically than countries with fewer or no resources. However, this has proven to be untrue in many countries as a result of 'undesirable side effects' (Frankel, 2012). They are especially African countries and include Nigeria, where the Niger Delta region has been living in a poorer state than other regions of the country. In the Niger Delta, the undesirable side effects that Frankel (2012) referred to as the reason for the resource curse have been multiple incidents of land, water, and air pollution such that the means of livelihood of the inhabitants of the region have been constantly threatened (Bodo and Gimah, 2020). For a region that is richer than others in terms of resources, it is poorer than others in terms of development.

This study, therefore, discusses the resource curse in Nigeria, depicting the circumstances of the Niger delta and the implications of allowing the resource curse syndrome to dominate the economy. It sets out the policy and approach of the Government that has not translated into effective ways of addressing the phenomenon. It thereafter demonstrates how the challenges in the Niger Delta can be addressed and concludes with the need to prioritize the legitimate claims of the people of the Niger Delta.

\section{THEORETICAL PERSPECTIVES OF THE RESOURCE CURSE}

Research that has been conducted over the years has confirmed that natural resource endowments in resource-rich countries have not been utilized appropriately for the achievement of development of the countries (Auty, 1993). Many countries rich in these resources have been faced or bedevilled by challenges that have led to poor economic development, social conflicts and political unrest (Collier and Hoeffler 2005). Therefore, the theory postulates that there is a link between natural resources and underdevelopment (Adeboye, 1999). The premise of the proposition is that countries rich in natural resources have the tendency to neglect other sectors of the economy, focusing solely on natural resources for their own development. In countries exhibiting the syndrome, the focus is on the resources and actions are largely not directed at translation of the resources and diversification of the economy to achieve optimal economic transformation. The resource thesis offers an explanation of these attributes. It is therefore not much of a surprise that the people of the Niger Delta have redirected their strategy to challenge the ill feelings through agitation over the years. One such earlier agitation was led by Isaac Adaka Boro, who was later charged with treasonable offences by the Nigerian Government (Ikporuko, 2018). Much effort will need to be directed by the Nigerian Government for the betterment and rising of the people of the Niger Delta region out from poverty. 
The score card in the Niger Delta region is not one that encourages economic transformation because of corruption. The establishment of the Niger Delta Development Commission (NDDC) was meant to address the challenges that have been retarding the growth of the Niger Delta region (Omotola, 2007). The establishment of the NDDC was expected to result in resource transformation benefits, but it turned out to be a tool for political patronage and rent-seeking. Over the years, the Ministry of Niger Delta Affairs was also developed. The Dutch Disease has come to be associated with a syndrome whereby success in the natural resources sector does not apply to other sectors of the economy. There is usually a concentration of labour and capital of the state on the development of natural resources, whilst other sectors of the economy are abandoned (Brincikova, 2016). The capital development of the natural resources sector is to bring about full maximization of the sector. The resources, therefore, create further wealth for the nation at the detriment of the other sectors.

\section{LEGITIMATE EXPECTATIONS OF THE PEOPLE OF THE NIGER DELTA}

Nigeria is a Sub-Saharan African country that is located within the Gulf of Guinea region of African states. Nigeria is a federating state comprising of thirty-six states and a Federal Capital Territory in Abuja. The Niger Delta region is made up of the oil-producing regions of Nigeria and includes Abia, Akwa-Ibom, Bayelsa, Cross-River, Delta, Edo, Imo, Ondo and Rivers States (Ajodo-Adebanjoko, 2017). Nigeria is rich in oil and gas and is a notable country internationally, given its geographical location within the Gulf of Guinea. The proven reserves are said to be about 37 billion barrels, and the gas reserves are put at about 186 (Akinpelu and Omotosho, 2017) to 187 trillion cubic feet (Onyi-Ogelle, 2017).

The region is densely populated, with about 30 million people living within $70,000 \mathrm{~km}^{2}$ (Asanebi, 2016). Bayelsa State has a population of 2 million people; Cross River State has 3.5 million people; Abia State has 3.5 million people; Edo State has 3.9 million people; Ondo State has 4.1 million people; Imo State has 4.7 million people; Akwa Ibom has 4.7 million people; Delta State has 4.9 million people; and Revers State has 6.2 million people (National Bureau of Statistics, 2017).

The Niger Delta is therefore of strategic importance to the country because of the abundant natural resources it has, which are the mainstay of the Nigerian economy. When oil and gas are discovered in a country, it is expected that the people should reap the benefits of the development of oil and gas in their region. Oil and gas are perceived as being able to generate prosperity. The benefits are in different folds. Exploration and production should provide citizens with jobs and opportunities (Fajana, 2005). Various forms of jobs should be created, both for high-skilled and low-skilled workers in the oil and gas industry. Typically, the oil and gas sector should create the opportunity for this. This will include scientists, geologists, engineers, lawyers, and accountants, among others. There is also an avenue for low-skilled workers such as technicians, artisans, and menial workers. This will lead to a reduction in the unemployment rate and the exposure of more people to good standards of living. In the same token, it is expected that there will be businesses operating in the region. Investment in the sector should lead to many economies of scale.

The business of oil and gas should provide an avenue for the development of a different fleet of businesses. It will be expected that there will be a transformation through infrastructural development. Oil and gas companies operating in the region should be able to develop infrastructural projects in the region where they operate. It has been expressed that because the Nigerian Government has been insensitive and unresponsive in addressing the plight of the Niger Delta, there has been an increase in the deterioration of transportation infrastructure, leading to living standards being made more costly and very unbearable (Adegbenle and Olatunji, 2016). The argument offered here is that the agitation of the people of the Niger Delta has been a product of the resource curse syndrome that has affected the nation generally.

The UNDP (2006: 15) reported that the human development index (HDI) score involves:

"a measure of well-being encompassing the longevity of life, knowledge and a decent standard of living, remains at a low value of 0.564 (with 1 being the highest score). At the same time, these ratings put the Niger Delta at a slightly higher level than Nigeria's overall HDI of 0.453 , the area rates far below countries or regions with similar oil and gas resources. For example, the HDI for Saudi Arabia in 2000 stood at 0.800 , while in 2003, the United Arab Emirates, Kuwait, Libya, Venezuela and Indonesia achieved scores of $0.849,0.844,0.799,0.772$ and 0.697 , respectively".

The state of affairs has not changed as people still do not enjoy an adequate standard of living. The people of the Niger Delta region have been experiencing the direct impact of the exploitation of petroleum resources since the first operations at the Oloibiri oil wells (Raji and Abejide, 2013). Oil exploration and production leave the region in abject poverty and environmental depravity. The expectation of the region is that there should be development. The people of the Niger Delta legitimately expect that from the proceeds of the oil exploited in their region, they should have a share that translates to the good of the region. The exploitation of the resources should be commensurate with the level of development in the region. Democratic governance is supposed to avoid the authoritarian repression of the Niger Delta people and grant them sufficient benefits from the proceeds. One serious 
concern, therefore, is that with the spread of oil and gas activities in the Niger Delta, the sustainability of the region has been questioned (Ugboma, 2015) and has remained a reference point on how not to manage petroleum resources.

\section{EXHIBITING THE SYMPTOMS OF THE RESOURCE CURSE IN THE NIGER DELTA}

\section{The Oil Centric Economy of Nigeria}

Shell was the first company to be given the opportunity to invest in the oil and gas sector in Nigeria (Raji and Abejide, 2013). The discovery of oil and gas saw the development of the sector with multinational oil corporations participating in the exploitation of oil and gas and paying money into the coffers of the Government in the form of fees, rents, royalties, profits, and taxes. The proceeds, therefore, form an important share of foreign exchange earnings as they are usually made in foreign currency, particularly the U.S. dollar, and constitute about $86 \%$ of the country's export revenue (Organisation of Petroleum Exporting Countries (OPEC), 2020).

Nigeria falls within the Gulf of Guinea and is placed as an advantage as one of the countries within the region which is very rich in oil and gas resources (Germain and Armengol, 1999). Nigeria is an oil-producing country that has benefitted from windfall profit from oil and gas. Nigeria is in a state of paradox because of its failure to translate the development it has made in the economy for the good of the people. The country lives in circumstances that have adversely affected the quality of life. The story of the case of the nation in the development field has been once referred to as that of a paradox of plenty (Edame and Efefiom, 2013).

The impact of the monolithic nature of the Nigerian economy has been seen in the state of the country's economy in the wake of the COVID 19 pandemic, which further occasioned a crash in global oil prices. The country was said to have drifted into a recession (World Bank, 2020), and so the Government could not meet the overhead costs of the country. While international oil prices continue to fall, there has been no corresponding drop in domestic oil prices, and the fuel pump price of domestic petroleum products has increased, making it more unbearable for the people.

The understanding of all is that the Niger Delta is associated with repression of the people of the region, with most of them living in the creeks, while the benefit of the resources in the region is being translated into other development initiatives. There has also been an offshoot of scholarships in the areas of corporate social responsibilities. This corporate social responsibility trend appears to make oil companies be more responsible. However, because of the neglect of the Government in the oil-rich regions, the citizens residing in those regions have turned to the oil companies for the production of basic and social amenities. It is inarguable that the oil companies have a moral obligation to carry out infrastructural development in the region. However, the trend of calling upon the oil companies to effectively execute capital projects that would have ordinarily been carried out by the Government has been a major concern. There is an emerging arrangement for the use of community development communities that implement community development agreements or memorandums of understanding with oil companies. Members of the committees are drawn from traditional rulers, community leaders and youths. The challenge that has emerged over time is the fact that some members of the committee ended up protecting the interest of the companies at the expense of the communities (Ebiede, 2011). This has led to suspicion and lack of trust in the communities, thereby fuelling riots.

The idea behind governance also includes the allocation of resources; this means that the national budget should be part of the resources that should be directed to infrastructural development. This appears to be limited, with the people of the Niger Delta relying on oil companies to do what is necessary to maintain their standard of living. In turn, the oil companies see this reliance as the grant of a social license to operate (Idemudia, 2009). The idea of social license to operate is that the oil companies want to be socially accepted in the places of operation (Mollat and others, 2016). If the oil companies obtain the requisite licenses and approvals from the Government but fail to get support from the public, it becomes a problem for them. This can adversely affect their operations. However, they may make the community buy into their activities by recognizing that the communities are stakeholders in their operations. That could be done through infrastructural development for the betterment of the people, the offering of scholarships, and capacity building to allow for their participation in the supply and rendering of services to the oil companies. All these are being prioritized, but it must be important to note that the major ill feelings are that there are no developed mechanisms to measure the effect of extent oil companies should contribute to the community. This is complicated because the Government's presence is not felt as it ought to be.

\section{Economic Implications}

Economic growth and development should involve a variety of resource development. Thus, both human and natural resources should be put together for the actualization of development. The national resources should not be limited to a particular resource; there should be a mixture of the resources for the good of the nation. It is shown that there are economic consequences of the resource curse in the Niger Delta. The agricultural sector in Nigeria has not been able to produce much value for the country because of neglect (Yakubu and Akanegbu, 2015; Ko, 2014). Nigeria has initiated different policies on agriculture, but most were abandoned because of the attention 
paid to the development and utilization of petroleum resources.

The consequence of oil exploration and production without consideration for diversification has had an adverse impact on the economy of Nigeria and the people of Nigeria. The attention of everyone in the nation is towards the blessings that oil has to offer in terms of job creation and infrastructural development. It would be expected that with the development advanced in the Niger Delta, much would have been achieved in the area of development of infrastructure that would have in turn transformed into wealth conversion for the nation. The resources themselves that ought to have served as a means of meeting the needs of the people have not been much attained. Much is felt in the economic crisis all over the country, with the level of inflation going high (Doguwa, 2012) because the proceeds from oil and gas, which are the central focus of the economy, have not been translated or distributed for the good of the people of the Niger Delta.

\section{Environmental Implications}

Environmental quality and management are central to natural resource governance in any country. Where natural resource exploitation does not compensate the environment, there is a tendency that there are risks that will affect the quality of life of people. The life of the people of the Niger Delta is then put at risk. The consequence of the current regime is that there is a case of abandonment of environmental standards with much focus on exploitation and production without minding the environmental consequences of the activities. According to Friends of the Earth International (2021): "Every year, 16,000 babies die as a result of the pollution, and life expectancy in the Delta is ten years less than in the rest of Nigeria". This captures one of the onerous situations ions encountered by the people of the Niger Delta.

The oil and gas sector has been very much responsible for different pollution incidents ongoing in the Niger Delta (Oghenetega and others, 2021). One of the culprits that have been identified is the multinational oil corporation, particularly Shell, for its notoriety. The flaring of gas in large quantities has been a major bane of the exploitation of the country's petroleum resources (Moffat and Linden, 1995). Nigeria is adjudged a major leader in the flaring of associated gas in the course of oil production. The multinational oil companies have been indulged in overtime by the Government of the country. They act with impunity, with no repercussions for their actions that are harmful to the environment.

The watermark of the activities of the shell and its repression of the people of the Niger Delta is well documented, as can be seen in the UNEP report on Ogoni in the Niger Delta. The report showed large-scale impunity and neglect of the Niger Delta people. One area affected by the activities is seen in the fishing rights of the people. The pollution has affected the region.

It is confirmed that if the activities of degradation in the Niger Delta region remain unchecked, there may be a case of ecological disaster for the people of the Niger Delta (UNDP, 2006). Environmental degradation from the activities of oil companies has many consequences for the people of the Niger Delta, who were previously largely self-sufficient (Okonta and Oronto, 2001). There are also cases where oil spillage has affected agricultural lands. Farming has been a problem, thereby making farmers not have successful yields. As the consequences of the pollution continue, different actions are brought in court to challenge the pollution. It has been further found that cases in the Nigerian courts are delayed for very long durations, due mainly to technicalities that lawyers rely mainly on to delay cases. Some aggrieved people have severally decided to seek justice in other countries where multinationals have their headquarters or operational bases. A good example is seen in the case filed against Shell in the Netherlands by Milieudefensie, which is also known as Friends of the Earth. The Hague Court of Appeals found that Shell was liable for the spill from its oil pipelines in the Oruma and Goi communities and awarded compensation of 100,000 euros as damages (Business \& Human Rights Resource Centre, 2021). In the same token, the highest court in the United Kingdom, the U.K. Supreme Court, has held that the oil-polluted communities can rightly bring an action against Shell before English courts. Thus, the court gave the nod for the Bille community and the Ogale people of Ogoniland to proceed with their action against Royal Dutch Shell (BBC, 2021). Shell had earlier in 2015 accepted responsibility for two major oil spills in the Niger Delta's Bodo Community and agreed to pay compensation of $£ 55$ million (\$76 million) as well as assist with clean up (Khalid, 2021).

Another pollution activity has been seen in the black suit in the Niger Delta region, where there are stains in the environment. A study from the collection of rainwater in the Warri area and its environs in the Niger Delta confirmed the presence of a large amount of lead beyond the normal level and a high P.H. value, thereby indicating the presence of acid rain (Olobaniyi and Efe (2007). There is a need to address the consequences and ensure that there are no adverse effects as a result of the consequences. The impact on quality of life is felt as there is a likely rise in respiratory diseases such as asthma and bronchitis (Yakubu, 2018). There is also the risk of dangerous illnesses such as cancer because of the exposure to chemicals released in the process of exploration and production in the Niger Delta region (Ukpere and others, 2018).

The Niger Delta region has also seen cases of illegal refineries. The lack of essential construction requirements in refineries leaves huge environmental imprints on the environment. The illegal refiners see it as business as usual. The prolonged consequences of the release of these chemicals into the environment will, in the 
long run, impact food quality and the healthy living conditions of the inhabitants.

The condition further confirms the oil-centric nature of the economy and the attendant resource curse that has been deeply rooted. Thus, addressing pollution means there could be high-handed regulation, which may mean paying heavy amounts as a fine. The reliance on the proceeds of oil and gas from the oil companies places the Government in a dilemma of not being in a position to promote oil and gas in the region of Nigeria. The consequence of huge penalties or cancellation of licenses for the production of oil and gas by defaulting companies is a shortfall in the federation account. The implication, therefore, will be that there will be continuous pollution by the oil companies. This is a case of regulatory capture as the Government is at the mercy of the oil companies. It is also very relevant to the issue of pollution haven theory, which holds that investors are much more likely to invest in regions with less stringent environmental protection measures. Pollution is cheaper because it does not encourage the use of the best available technologies, which are quite expensive. They use cheaper technologies that are not environmentally friendly to scale up their investments. In such regions, the environmental costs are not factored into the energy planning and budgeting of the companies. The attendant market failure reflected in the resource curse syndrome offers benefits to oil companies in terms of their balance sheet. The essence of most businesses will be profit-making, which is highly prioritized at the expense of the well-being of the people. Multinational companies who would, in the normal course of things in their home countries, not be involved in pollution would engage in such practices in another country where they could escape being subjected to fines or even having their officials serve jail terms for their prejudiced attitude towards the environment.

Because of the nature of petroleum resources or other natural resources, which draw different participants such as the Government, multinationals, citizens, communities, civil societies, and even the political class, there is a tendency that a crisis will emerge in the question of the allocation of resources and their utilization. There will be a move towards selflessness or economic gains. Thus, for a good government, the concentration will be on how the resources will be tapped and developed for national prosperity. For a bad government, the central concern will be how the oil resources can be used for the actualization of political gains and other parochial interests. On the other hand, the oil companies will want to make a profit, which is their primary motive for operating in the oil and gas industry. In the bid to maximize profit, they may either act as good or bad corporate citizens in the country of their operations.

The communities and civil societies where oil and gas are located are much more likely to develop a feeling of neglect if the proceeds from oil and gas are not effectively utilized to their benefit. Whatever the situation, there are a series of vested interests, and the inability of the Government to manage them well will lead to crises. Crises usually start in the form of protests and may eventually lead to wars or the emergence of rebels or terrorists, as the case may be. Notable conflicts are seen in the case of Angola, Iraq, Libya and the Nigerian Niger Delta. They are referred to as classic examples. The conflict in the Niger Delta needs urgent attention. The struggle of the people of the Niger Delta has been ongoing and took a greater dimension with the activities of Isaac Adaka Boro (Ikporuko, 2018). The Niger Delta has been seen with much suspicion in its struggle for the benefits of translation for the good of the people. The lives of the people in Niger have witnessed different struggles. The crisis also saw the Kaiama Declaration of 1998 (Takon, 2013; Nwajiaku, 2005). There has been notable agitation by the people of the Niger Delta, most especially after the execution of Saro Wiwa and eight others in November 1995 by the military Governor of Nigeria led by the late General Sanni Abacha. One of the most prominent agitations was led by Asari Dokubo, who largely called for a review of Nigeria's arrangements and gave new meaning to the Niger Delta agitation (Asuni, 2009). The Movement for the Survival of the Ogoni People (MOSOP), the Niger Delta Volunteer Force, and the Movement for the Emancipation of the Niger Delta (MEND) are notable agitation groups that have led the Niger Delta struggle.

There are cases of vandalism of oil pipelines in the Niger Delta. Some of this vandalism has led to infernos that consumed the people. A notable incidence was the Jesse tragedy that led to the loss of over a thousand lives in1998 (Adeyeri, 2012). Pipeline vandalism has become a lucrative business, with vandals scoping fuel for sale. The steps taken by Asari Dokubo were challenged rigorously by the Federal Government. There were other agitations, such as the one led by Tomoplo (Asuni, 2009). Tompolo fought the Government and has been subjected to a series of attacks. Lives and property, and oil and gas installations have been lost because of the agitation. The repression of the people of the Niger Delta was also seen in the Odi crisis, where the military wiped out a whole community, killing over two thousand people, mainly women and children (Courson and others, 2006). The consequences of these have not augured well for the development of the Niger Delta. Even on the high seas, piracy has been rampant as a way of expressing agitation (McNamee, 2012).

The crisis in the Niger Delta took a new turn with the emergence of the Niger Delta Avengers in 2016 (Niworu, 2017). The Niger Delta Avengers targeted different installations in the Niger Delta, leading to the serious closure or abandonment of oil and gas operations in the Niger Delta. The development, however, constituted a huge loss to the economy that has been reliant on oil and gas for foreign exchange and even electricity generation (Niworu, 2017). Due to the activities of the Niger Delta Avengers in the region, Shell Petroleum's obligation under a gas supply contract for electricity generation could not be performed. Shell cited force majeure, circumstances beyond 
its control, as the reason behind its not meeting the supply obligations for the supply of gas to the processing plant (Energy Voice, 2016). The Shell Forcados 48-inch pipeline underwater bombing was carried out by the Niger Delta Avengers. The implications for the economy remain enormous for the nation, and it has created pressure on the Government and even the companies carrying out operations in the Niger Delta.

\section{Corruption in the Niger Delta Region}

Nigeria remains one of the countries that has been rated to have experienced a series of recorded corruption in dealing with oil revenues. It is believed that the resources of the Niger Delta have ended up in private hands because of corruption (Donwa and others, 2015). Many cases of corruption have been swept under the carpet. For example, there was the House of Representatives report on subsidies that led to a case of selective prosecution in the country. There is a rise in corrupt practices that have affected the NDDC. The NDDC was established to provide for the development of the region through creating infrastructure, improving the economic well-being of the region, and promoting healthy environmental practices. There is a requirement to use the NDDC as an instrument for the actualization of the development of the region. Oil companies are required to make payments into the fund, which should be used for the execution of the projects initiated by the NDDC for the region. The awarding of contracts has been based on corrupt practices. Most contracts are not executed and remain abandoned. The National Assembly invitation of the executives and the Minister for Niger Delta revealed a seriously sour taste of how corruption has deeply permeated into the Niger Delta region.

During the reign of Alhaji Yaradua, the Government, in a bid to end the crisis in the Niger Delta crisis, initiated the amnesty programme as a way to address the crisis in the region (Thom-Otuya and Eremie, 2011). With the initiation of the amnesty programme, amnesty was granted to the militants in the Niger Delta region. The arrangement led to the disarmament and submission of arms by repentant militants. In 2009, 2760 assorted weapons and other ammunition numbered 287,445 were surrendered to the Government (Ebiede, 2011). A series of programmes were put in place to integrate the surrendered militants back into society. The programmes include the training of militants in different apprenticeships, sending them abroad for studies and the acquisition of skills. The development and initiative, however, has been bedevilled by corruption within the coordination of the amnesty programme. A series of allegations have been levelled against the fraudulent activities of the officials of the programme (Ogele, 2020).

With the coming of democratic rule, it was the perception that the prolonged military rule in the country adversely increased corruption in the country. Democratic governance was considered as a way forward for the initiation of democratic values in the country and the promotion of good governance, which had been much affected by the long period of authoritarian rule in Nigeria, where there was a lack of due process and observance of human rights. The Corrupt Practices and other Related Offences Act 2000 (which established the Independent Corrupt Practices and Other Related Offences Commission (ICPC)) and the Economic and Financial Crimes Commission (EFCC) Act of 2002 were passed by the Nigerian legislative arm, the National Assembly, and they were assented by the President, Chief Olusegun Obasanjo. The ICPC and the EFCC are not living up to the exceptions of ensuring that corruption arising from the oil and gas sector, as well as other financial crimes, go unpunished. There are, however, cases that are ongoing but have yet to be concluded.

Multinational oil corporations have instances of being alleged to have bribed community leaders instead of attending to the needs of the people. Therefore, activities required to be carried out in the necessary environmental impact assessment are done in collaboration with the leaders who have connived with the companies and failed to challenge activities that ought to have been addressed in environmental impact assessment reports (Ebiede, 2011). One may refer to some natural resource-rich countries as corruption havens. The OECD has put in place codes of practices for multinational corporations. One of the goals of the OECD Guidelines is to check the activities of multinationals and caution them against being involved in actions that make them complicit with host governments in abuses or corrupt practices. The United States also has legislation that checks against multinational corporations' corrupting or enticing public officials of other countries (Jones and Haile, 2011). Most developed countries have such arrangements, and oil companies have been tried for complicity in corrupting officials. In the Niger Delta, there were allegations that Shell used the police and the military to suppress the people of the Niger Delta (BBC, 2017). Cases of brutality and rape by law enforcement agencies involved in the repression of the people of the Niger Delta region were also enormous.

\section{Transparency Challenges}

Internationally, there are a series of initiatives worldwide for the development and translation of natural resources for the good of mankind. Most of the initiatives on the governance of natural resources call for nations to utilize economic development in their resources through the development of international mechanisms that promote transparency and accountability in the oil and gas sector. Good examples of such are the Natural Resources Charter, the Extractive Industry Transparency Initiative (EITI), the Generally Accepted Standards on Management of Sovereign Wealth Funds, and the Santiago Principles. The Natural Resources Charter has initiatives that promote 
the development of the various aspects of natural resources for development. It has transparency as a key aspect of the actualization of natural resources. The Santiago Principles also set practices and standards for the management of natural resource wealth through transparency. The EITI standards have substantially taken the lead in the transformation of extractive industries through the promotion of transparency practices. The EITI has a standard of best practices for the initiation of participation of the members in the development of national wealth based on transparent tenets. Compliant countries are required to domesticate the practice through establishment institutions. These initiatives are directed at transparent practices in the oil and gas sector in Nigeria if the country decides to integrate such best practices for the good of the oil and gas industry. Transparency of international oil and gas operations and the impact on domestic oil and gas governance is a key instrument that will need to be put in place for Nigeria to actualize optimum development in the oil and gas sector. Compliance with EITI has taken a legal tone in the integration of transparency. The Government of Nigeria passed into law the Nigerian Extractive Industry Transparency Initiative (NEITI) Act 2007. The establishment of NEITI is expected to increase transparency in the oil and gas sector and the extractive industry.

\section{Implications for Foreign Direct Investment}

The geopolitics of energy has long been a contentious issue internationally. An assessment of the situation will reveal that there is a current change in the dynamics in international energy relations, as has been seen with oil and gas being discovered in new frontiers. The era has changed wherewith the crisis in the Niger Delta; the international oil market would have been adversely affected. Investors are moving away from the region of the Niger Delta (Nwogwugwu and others, 2012) and possibly selling their assets. The recent divestment of Chevron's assets in Nigeria (Addeh, 2021), as well as Shell Nigeria assets in the Niger Delta (Arise News, 2021), is a consideration worthy of mentioning in the impact of the Niger Delta crises on foreign direct investment in Nigeria. Where investors are not guaranteed the needed safety in the region owing to the crises that have been occasioned by the failure of the current governments to better the lives of the people of the Niger Delta, it has become a challenge that should be grappled within the country.

Besides this development, there is another potential in other African countries that are now being endowed with hydrocarbon resources. One of Nigeria's neighbours, Ghana, made its discovery of hydrocarbons in commercial quantities in 2007 (Graham et al., 2020). This development saw Ghana embarking on commercial exploitation of its hydrocarbon resources to meet the good of the people of Ghana. Besides Ghana, Sierra Leone, Liberia, and the Gambia have shown promises (Nyemah, 2011). There is also potential in countries in the East African region. Oil and gas companies would rather direct their investments into climates where they will not be exposed to risks occasioned by the inability of the nation to manage its resources in a manner that the oil-rich communities can buy into such projects.

\section{POLICY CONSIDERATIONS IN ADDRESSING THE RESOURCE CURSE}

Giving the configurations of the system of Government operating in Nigeria, which is a federalist system of Government, it can be said that the country operates fiscal federalism. Under the fiscal federalism arrangement, the petroleum resources belong to the Government of Nigeria, and the revenue derived from them is shared between the federal and the federating units, with $13 \%$ going to the states based on the principle of derivation. By implication, the way and manner in which the state utilizes the revenue is within its own discretion. The Federal Inland Revenue Services collect the respective petroleum profit taxes from oil and gas companies engaging in petroleum operations and pay them into the federation account in accordance with the provisions of the Constitution of Nigeria (Federal Government of Nigeria, 1999).

The Niger Delta region has over the years lived with this form of arrangement with the feeling of being shortchanged given the fact that it has the resources. The stance of the Niger Delta has been that the resources should be fully within its control. Policy documents show that, as part of the agenda of the Government, it is believed that much effort should be directed towards the promotion of the common good of the people of Nigeria, and so the Government initiated a reform in the oil and gas sector. This reform process saw the development of the petroleum industry in the form of the Oil and Gas Implementation Community (OGIC) that was initiated by the Government. The OGIC was put in place to develop the oil and Gas Policy and initiated the process leading to legislative reform in the oil and gas sector. The OGIC put in place the first draft of the Petroleum Industry Bill in 2008/2009, which was just recently signed into law (KPMG, 2021). The politicking in the country and the various entities interested in the oil and gas industry did not create the enabling environment for the passage of the Bill. Now that the Bill has been passed, the interests of the Niger Delta people still remain undermined. The policy of the Government for the purpose of acquisition of resources will need to factor in arrangements for accountability and transparency in the system. There have been some important developments in the process of reform, with much attention drawn to the Niger Delta region through the road map of the Ministry of Petroleum Resources under the direction of the then Minister of State for Petroleum, Dr Ibe Kachikwu.

There is much that will need to be put in place to remove opacity in the oil and gas sector regime in developing 
countries such as Nigeria. Information asymmetry is very important to the development of informed decisions for the protection of resource leakages in the country. Proceeds accruing to the Government will need to be made available for the scrutiny of the public from time to time. The promotion of transparent practices in the oil and gas sector will also need to be addressed. The Petroleum Industry Bill eventually had a very long history, with reform taking about 20 years before it was finally passed (KPMG,2021). The Bill was challenged several times before the National Assembly, with different versions going into parliament. At one point, it was considered that there should be a fragmented rather than a composite bill before the National Assembly. At some points, the Bill was divided into segments, such as the Petroleum Industry Governance Bill, the Host Communities Entitlement and Protection Bill, the Petroleum Industry Administration Bill, and the Petroleum Industry Fiscal Bill. The various Bills were eventually jettisoned in favour of a composite Bill, which eventually led to the passage of the Petroleum Industry Act 2021. The Bill was passed by both the National Assembly on 1 July 2021 (Detail Solicitors, 2021), while it received presidential assent on 16 August 2021 (KPMG, 2021).

The passage of the Petroleum Industry Bill into law underscores a challenge in the oil and gas sector in the country, which is the resource curse that created the various compelling interests with the legitimate and illegitimate interests. The Bill made some particular reference to the recognition of host communities to include communities which pipelines run through as against the previous understanding of the concept, which was seen from the view that host communities include communities where the oil and gas companies carry out petroleum operations. This will be where the operational bases are in the Niger Delta, such as oil and gas platforms or drilling sites. The allocation of 3\% of operating expenditure (Agbakwuru, 2021) to host communities to be managed by the host community funds is considered to be a shortfall by the people of the Niger Delta. The law requires that the companies under obligation to make payment into the fund "shall make an annual contribution to the applicable host communities development trust fund of an amount equal to 3\% of its actual annual operating expenses of the preceding financial year in the upstream petroleum operations affecting the host communities for which the applicable host communities development trust fund was established". The agitation has further been heightened by the fact that communities that did hitherto not host communities will share the proceeds of the oil and gas. There has been a much-awakened struggle with the passage of the Bill, which is believed to change the rules of the game.

The Federal Government has put in place a committee for the implementation of the Bill, and much will be expected. The outcome of the implementation of the reform introduced by the Petroleum Industry Act will go a long way to determine the extent to which the reform in the oil and gas sector will accommodate the aspirations of the people of the Niger Delta beyond the 3 per cent of the allocated resources, the way the funds are managed and whether oil and gas companies operating in the region will invest responsibly in the Niger Delta region where they have their operational bases.

On a critical look at the long title of the Petroleum Industry Act 2021, it is provided that "AN ACT TO PROVIDE LEGAL, GOVERNANCE, REGULATORY AND FISCAL FRAMEWORK FOR THE NIGERIAN PETROLEUM INDUSTRY, THE DEVELOPMENT OF HOST COMMUNITIES; AND FOR RELATED MATTERS". Chapter Three of the Act is specifically devoted to hosting community matters. The objectives of the chapter can be summed up to include encouraging long-term and sustainable prosperity within host communities; giving direct social and economic advantages from petroleum activities to host communities; increasing peaceful and harmonious coexistence between licensees or lessees and host communities; and building a framework to help host communities develop (Section 234, Petroleum Industry Act, 2020). There is an arrangement to put in place a trust fund for the management of the fund, which is known as the Host Communities Development Trust (Section 235, Petroleum Industry Act, 2021). The host community development trust is in charge of managing and supervising the administration of the funds contributed to it. The host community development fund is provided to have the objectives:

(a) finance and carry out projects for the benefit and long-term development of host communities;

(b) undertake infrastructural development of the host communities within the scope of funds available to the Board of Trustees for such purposes;

(c) facilitating opportunities for economic empowerment in host communities;

(d) advance and propagate educational development for the benefit of members of the host communities;

(e) support healthcare development for the host communities;

(f) support local initiatives within the host communities, which seek to enhance the protection of the environment;

(g) support local initiatives within host communities aimed at improving security;

(h) invest a portion of the available funds on behalf of the host communities; and

(i) assist in any other developmental purpose deemed beneficial to the host communities as may be determined by the Board of Trustees.

While the people of the Niger Delta have expressed dissatisfaction with the way in which the law resolves the issue of host communities, it is still awaited to see the extent of implementation and whether the corruption 
bedevilling the country, rent-seeking, and other parochial interests will not truncate the ideals behind the establishment of the host community funds.

\section{DECOUPLING THE RESOURCE CURSE FROM NIGERIA}

Having carried out an analysis of the resource curse phenomenon in Nigeria and taking a look at the current realities in the country, it is imperative that the study should look at the structural factors on which a serious reform to address the crisis in the Niger delta will need to be founded. Firstly, the nature of federalism operating in Nigeria fails to accommodate the actual principles of federalism in which there is a clear distribution of powers. The federalism practised in Nigeria largely gives many powers to the Federal Government that controls all petroleum and other natural resources. Ownership of petroleum resources is vested in the Government. This is also reasserted in the Petroleum Industry Act 2021, which states that: "The property and ownership of petroleum within Nigeria and its territorial waters, continental shelf and exclusive economic zone is vested in the Government of the Federation of Nigeria." Therefore there will be a need for constitutional review, which may address the question of ownership and possibly grant some forms of ownership and control to host communities.

The problem of corruption, rent-seeking, parochial interest will need to be addressed. It will be important that people found wanting to have exploited the people of the Niger Delta are brought to book through forfeiture of assets and serving of respective imprisonment terms as provided in the various laws of the land, such as the ICPC Act, EFCC Act, Penal Code, and the Criminal Code, among other numerous laws in the country that may be called to bear in the justice system.

Reassessment of the development plans of the country with a particular focus on the Niger Delta will need to be done, taking into account the core elements of the resource curse that will need to be addressed. To this end, diversification of the economy is expedient in meeting these needs. Oil revenue should be based on infrastructural development, an increase in agriculture, and investment in research and development for the deployment of technologies, as well as information and communication technologies.

Bringing the matters of transparency and accountability to the front burner is also very important. Most of the resources in the region end up in private pockets (Donwa and others, 2015), contrary to the dictates of law and policy and the overall objectives put in place by the Government to address poverty and infrastructural decay in the Niger Delta region. Nigeria has pledged to uphold the EITI standards. NEITI is an agency of the Federal Government with such responsibility. The Government will need to empower it and ensure that it discharges its obligation to promote transparency and accountability in the money that goes in and out of government coffers. International best practices should be an inspiration for the promotion of transparency. The role of corporate accountability is essential. Companies have operational bases in the Niger Delta region, and they are largely responsible for the degradation. The coming into effect of the Petroleum Industry Act should transform it into the mechanism for the promotion of a healthy environment in the Niger Delta. They should be made to be responsible for all crimes they commit to the environment and pay reparation for the activities. This is in line with best practices, as seen in the polluter pay principle. Companies responsible for pollution have to clean up and carry out environmental remediation and restoration.

Above all, reorientation becomes imperative to imbibe these standards and practices for the good of the people of the Niger Delta. Values will need to be changed across the various strata in the country and among the companies, regulators, and government officials. Addressing the resource curse will require good institutions to be in place (El Ansashy and Katsaiti, 2013). There should be concentration on the development of institutions with the capacity to address the problem.

\section{CONCLUSION}

Nigeria is one of the few hydrocarbon provinces in the world with abundant natural resources for the development of the nation. We should be able to translate our resources for the good of the nation. Every country endowed with petroleum resources should take steps to ensure that the resources are translated for the benefit of the people. Petroleum resources, for example, should be a source for the development of the economy. This means that in all aspects of development, resources are an important source of revenue. The distribution should be such that the general population has access to the product for the common good of all. Without such an effort being put in place, nations will continue to suffer and may not be able to manage their resources for the good of society. The people of the Niger Delta region of Nigeria remain the most short-changed in the history of Nigeria, with the region experiencing a series of pollution and other environmental degradation incidents. They have abundant petroleum resources, but these resources have not been properly or adequately utilized for their development. This has, in large measure, affected the distribution of economic benefits in the region. The life expectancy is very low. The meeting of their basic needs has not been attained. Efforts to channel the benefits of development have always been truncated. Much will need to be done for the greater good of the development of the people of the Niger Delta. The level of corruption in the region of the Niger Delta is high. Rent-seeking and political patronage is very high. 
It will be much more appropriate for the nation to reform the current ways in which natural resources are being managed. There should be an avenue for economic diversification in Nigeria. Much will need to be done by taking into account the need for restricting and revisiting the federal system in operation in Nigeria as well as the form of ownership of petroleum resources being practised. Criminalization of corruption and fraudulent practices, holding oil companies accountable, are also necessary. Steps will need to further be taken to integrate transparency in petroleum resource revenue management and planning in the country. Above all, there is a need for reorientation as a shift in values. Nigeria can only divorce itself from the paradox of plenty by taking proactive measures to address the threat of the resource cures that have bedevilled the country and the Niger Delta region, in particular.

\section{REFERENCES}

Addeh E. (2021). Nigeria: Chevron Sells 40\% stake in OMLS 86, 88 to Conoil (27 January 2021) https://allafrica.com/stories/202101270563.html, accessed 2 September 2021.

Adeboye T. (1999). Underdevelopment and natural resource abundance in Africa. Economic and Social Council: First meeting of the Committee on Natural Resources and Science and Technology. Addis Ababa.

Adegbenle B.O. and Olatunji A.A. (2016). Development of the water infrastructure in the estuarine part of Niger Delta to ameliorate the prevailing transportation. Global Journal of Researches in Engineering: E Civil and Structural Engineering, 16(5) 17-24.

Adeyeri O. (2012). Nigerian State and the management of oil minority conflicts in the Niger Delta: A retrospective view. African Journal of Political Science and International Relations 6(5): 97-103.

Agbakwuru J. (2021). PIB: 3\% for host communities, good starting point says PENGASSAN (13 August 2021) https://www.vanguardngr.com/2021/08/pib-3-for-host-communuties-good-starting-point-says-pengassan, accessed 2 September 2021.

Ajodo-Adebanjoko A (2017). Towards ending conflict and insecurity in the Niger Delta Region: A collective nonviolent approach. African Centre for the Constructive Resolution of Disputes, https://reliefweb.int/report/nigeria/towards-ending-conflict-and-insecurity-niger-delta-region, accessed 2 September 2021.

Akinpelu L. and Omotosho Y. (2017). Probabilistic estimation of potential gas reserves for the emerging Nigerian gas market. International Journal of Petroleum and Gas Engineering Research 1(2): 8-15.

Arise News, 'Shell Launches Major Divestment of Nigerian Assets, SPDC for Sale' (30 July 2021) https://www.arise.tv/shell-launches-major-divestment-of-nigerian-assets-spdc-for-sale/, $\quad$ accessed 2 September 2021.

Ariweriokuma, S. (2008). The political economy of oil and gas in Africa: the case of Nigeria. Routledge.

Ariweriokuma, S. (2008). The political economy of oil and gas in Africa: the case of Nigeria. Routledge, London Asanebi D.H. (2016). A Concise View of Niger Delta Region of Nigeria: An Interpretation of a Nigeria Historian' (2016) International Research Journal of Interdisciplinary \& Multidisciplinary Studies 2(10): 56-63.

Auty, R.M. (1993). Sustaining development in mineral economies: The resource curse thesis. London: Routledge.

BBC, 'Nigeria: Ogoni Widows sue Shell over Military Crackdown' (29 June 2017) https://www.bbc.com/news/world-africa-40443742, accessed 2 September 2021.

Brinčíková, Z. (2016). The Dutch disease: An overview. European Scientific Journal 12(10): 95-101.

Business \& Human Rights Resource Centre (2021). Nigeria: In a win against Shell, the Dutch court finds Shell Nigeria liable for oil spills \& Shell parent company has a duty of care to prevent future spills, https://www.business-humanrights.org/en/latest-news/nigeria-in-win-against-shell-dutch-court-finds-shellnigeria-liable-for-oil-spills-shell-parent-company-has-a-duty-of-care-to-prevent-future-spills/, accessed 2 September 2021.

Collier, P. and Hoeffler, A. (2005). Resource rents, governance and conflict. Journal of Conflict Resolution, 49: 625-633

Detail Solicitors (2021). Highlights of the Petroleum Industry Bill as passed by the National Assembly,https://www.detailsolicitors.com/highlights_of_the_petroleum_industry_bill_as_passed_by_the_ national_assembly, accessed 2 September 2021.

Doguwa S.I. (2012). Inflation and economic growth in Nigeria: Detecting the threshold level. CBN Journal of Applied Statistics 2(2): 99-124.

Donwa P.A, Mgbame C.O and Julius O.M (2015). Corruption in the oil and gas industry: Implication for economic growth. Arabian Journal of Business and Management Review 3(9): 1-16.

Ebiede T.M. (2017). Instability in Nigeria's Niger Delta: The post amnesty programme and sustainable peacebuilding. Friedrich-Ebert-Stiftung Peace and Security Centre of Competence Sub-Saharan Africa

Edame G.E. and Efefiom E.F. (2013). The trend analysis of oil revenue and oil export in Nigeria. IOSR Journal of Business and Management 10(3): 1-8.

El Ansashy, A.A. and Katsaiti, M.S. (2013). Natural resources and fiscal performance: Does good governance matter? Journal of Macroeconomics, 37: 285-298. 
Elias C. (2006). Odi Revisited? Oil and State Violence in Odioma, Brass LGA, Bayelsa State. Niger Delta Economies of Vorking $\quad$ Paper 4 7-r, http://geog.berkeley.edu/ProjectsResources/ND\%20Website/NigerDelta/WP/7-Courson.pdf, accessed 2 September 2021.

Energy Voice, 'Shell Declares Force Majeure on as Supplies to Nigerian Export Facility' (10 August 2016) https://www.energyvoice.com/oilandgas/africa/116663/shell-declares-force-majeure-gas-supplies-nigerianexport-facility/, accessed 2 September 2021.

Fajana S. (2005). Industrial relations in the oil industry in Nigeria. International Labour Office Working Paper 237, https://www.ilo.org/wcmsp5/groups/public/---ed dialogue/---sector/documents/publication/wcms_161189.pdf, accessed 2 September 2021.

Frankel J.A. (2012). The Natural Resource Curse: A survey of diagnoses and some prescriptions. HKS Faculty Research Working Paper Series RWP12-014, John F. Kennedy School of Government, Harvard University, https://dash.harvard.edu/bitstream/handle/1/8694932/RWP12-014 Frankel.pdf, accessed 2 September 2021.

Friends of the Earth (2021). Nigerian farmers and Friends of the Earth win oil pollution case against Shell in a historic ruling, https://www.foei.org/press_releases/victory-oil-shell-nigeria, accessed 2 September 2021.

Graham E., Gyampo R.E.V. and Tuokuu F.X.D (2020). A Decade of oil discovery in Ghana: Implications for politics and democracy. Ghana Social Science Journal 17(1): 31-57.

Ikporuko C.O. (2018). From Adaka Boro to the Niger Delta Avengers: The dynamics and management of the revolt in Nigeria's Niger Delta. International Journal of African and Asian Studies 43: 35-48.

Joelle G. and Christophe A. (1999). Gulf of Guinea: A deep offshore opportunity. The Journal of Energy and Development 25(1): 87-95

Jones M.D and Haile S. (2011). Multinational corporations and the foreign Corrupt Practices Act: A Legal Look at Transnational Business' (2011) 19-27

Khalid I. (2021), Fresh hope for justice, https:/www.bbc.com/news/world-africa-56041189, accessed 2 September 2021.

Ko V. (2014). Nigeria's "Resource Curse": Oil as an impediment to true federalism, https://www.eir.info/2014/07/20/nigerias-resource-curse-oil-as-impediment-to-true-federalism/, accessed 2 September 2021.

KPMG， 'Petroleum $\quad$ Industry $\quad$ Bill $\quad$ (PIB) 2021' https:/home.kpmg/ng/en/home/insights/2021/06/petroleum-industry-bill-pib-2020.html, accessed 2 September 2021.

KPMG, 'President Signs the Petroleum Industry Bill, 2021 into Law' (16 August 2021) https://home.kpmg/ng/en/home/insights/2021/08/president-signs-the-petroleum-industry-bill-2021-intolaw.html, accessed 2 September 2021.

Marclint E.T. (2011). Conflict Drivers: Environmental degradation and corruption in the Niger Delta Region (2011) African Conflict and Peacebuilding Review 1(1): 139-151.

McNamee, M. (2012). Piracy on the Rise in the Gulf of Guinea as Niger Delta Militants Move Offshore. Terrorism Monitor 10(15): 6-7.

Mollat K., Lacey J., Zhang A. and Leipold, S (2016). The Social Licence to Operate: A Critical Review. An International Journal of Forest Research 89(5): 477-488.

Niworu S.M. (2017). The Niger Delta Avengers, autonomous ethnic clans and common claims over oil wells: The paradox of resource control. African Research Review 11(2): 42-56.

Nwajiaku K. (2005). Between discourse and reality: The politics of oil and Ijaw ethnic Nationalism in the Niger Delta. Cahiers D Etudes Africaines 45(178): 457-496.

Nwogwugwu N., Alao O.E. and Egwuonwu C. (2012). Militancy and insecurity in the Niger Delta: Impact on the inflow of foreign direct investment to Nigeria. Kuwait Chapter of Arabian Journal of Business and Management Review 2(1): 23-37.

Nyemah R.G.M. (2011) Economics of Oil Discovery in West Africa: The Nigerian Experience, Regional Maritime University Journal 1: 43-58.

Ogele E.O. (2020). Corruption, national security, and amnesty programme in the Niger Delta region, Nigeria, from 2009-2019. African Journal of Social Sciences and Humanities Research 3(3): 28-46.

Oghenetega O.B., Ojengbede O.A., Okuntola M.A. and Ana G.R.E.E., (2021). Oil pollution and its impact on communities in the Niger Delta: A quantitative research approach. African Journal of Medicine and Medical Sciences 50(1): 57-67.

Okonta, I. and Oronto, D. (2001). Where Vultures Feast, Forty Years of Oil in the Niger Delta, Ibadan: Kraft Books Limited.

Olobaniyi, S.B. and Efe, S.I. (2007). Comparative assessment of rainwater and groundwater quality in an oilproducing area of Nigeria: environmental and health implications. Journal of Environmental Health and Res (6) 2: 111-118. 
Omotola, J.S. (2007). From the OMPADEC to the NDDC: an assessment of state responses to environmental insecurity in the Niger Delta, Nigeria. Africa Today. 54(1): 73-89.

Onyi-Ogelle O.H. (2017). The legal regime for Nigerian gas. Nnamdi Azikwe University Journal of International Law and Jurisprudence 8(2):151-160.

OPEC (2020). Annual Statistical Bulletin. OPEC.

Raji A.O.Y. and Abejide T.S. (2013). An Assessment of environmental problems associated with Oil Pollution and Gas Flaring in the Niger Delta Region Nigeria. Arabian Journal of Business and Management Review 3(3): 48-62.

Raji A.Y. and Abejide T.S. (2013). Shell D'Arcy exploration \& the discovery of oil as important foreign exchange earnings in Ijawland of Niger Delta, the 1940s-1970. Arabian Journal of Business and Management Review 2(11): 22-33.

Takon N (2013). Non-state violence, state responses, and implications for human rights and scrutiny in the Niger Delta. Journal of Human Rights in the Commonwealth 1(1): 38-55.

Thom-Otuya B.E.N. and Eremie V.T. (2011). Amnesty to Niger Delta Militants: Challenges and opportunities for future peace missions. An African Journal of Philosophy 13(2): 70-77.

Tombari B. and Gbidum, G.B. (2020). The pollution and destruction of the Niger Delta ecosystem in Nigeria: Who is to be blamed? European Scientific Journal. 16(5): 161-182.

Ugboma P.P. (2015). Environmental degradation in oil-producing areas of Niger Delta Region, Nigeria: the need for sustainable development. International Journal of Science and Technology 4(2): 75-85.

Ukpere D.P.T, Clifford A.B, Ojule E.S.C. and Ottah C.R. (2018). Impacts of Air Pollution in the Niger Delta of Nigeria. IIARD International Journal of Geography of Geography and Environmental Management 4(4): 1322.

UNDP (2006). Niger Delta Human Development Report. UNDP.

Uwafiokun I. (2009). Oil extraction and poverty reduction in the Niger Delta: A critical examination of partnership initiatives. Journal of Business Ethics 90: 91-116.

World Bank, (2020). Nigeria's Economy Faces Worst Recession in Four Decades, says New World Bank Report, https://www.worldbank.org/en/news/press-release/2020/06/25/nigerias-economy-faces-worst-recession-infour-decades-says-new-world-bank-report, accessed 2 September 2021.

Yakubu M and Akanegbu B. (2015). Neglecting agriculture and its consequences to the Nigerian Economy: An analytical synthesis. European Journal of Research in Social Sciences 3(3): 18-27.

Yakubu O.H. (2018). Particle (Soot) pollution in Port Harcourt Rivers State, Nigeria - Double air pollution burden? Understanding and tackling potential environmental public health impacts. Environments 5(2): 1-22. 